\title{
Italian Theories About Accounting Measurements From the Twenties to the Sixties: Looking for Underlying Tendencies
}

\author{
Enrico Gonnella \\ Associate Professor of Financial Accounting and Business Valuation \\ University of Pisa, Pisa, Italy \\ E-mail: enrico.gonnella@unipi.it
}

Received: November 7, 2020 Accepted: November 30, 2020 Published: December 30, 2020

doi: 10.5296/ijafr.v10i4.17925 URL: https://doi.org/10.5296/ijafr.v10i4.17925

The quotations of Italian writings have been translated into English by the authors of the paper.

\begin{abstract}
The main subject of this paper is the theory of accounting valuations as observed from a historical perspective. In particular, this research concerns the most significant theoretical concepts developed through the Italian doctrine between the 1920s and the 1960s. This period was a historical phase of great cultural ferment, characterised by the progressive deepening of the subject of accounting valuations by Italian scholars.

Most of the attention has been focused on those scholars who, by developing theses among the most innovative and original, made significant contributions to the advancement of Italian accounting: Gino Zappa, Vittorio Alfieri, Francesco De Gobbis, Pietro Onida, Lorenzo De Minico, Alberto Ceccherelli, and Egidio Giannessi. These scholars, aware that the valuative problem could not be addressed with simple valuation rules, were interested in finding general principles that could be useful models of behaviour for the accounting practise. These principles made it possible to understand that valuation, being a process that transcends the simple mechanistic application of predefined rules, requires the formulation of a judgment based on the observation of the firm's specific characteristics and of those of the external environment in which it operates.
\end{abstract}

The analysis allowed the main trends in the examined evolutionary process to be identified, including the progressive relativisation as well as the increasing subjectivity of values, the 


\section{$\triangle$ Macrothink}

International Journal of Accounting and Financial Reporting

ISSN 2162-3082

2020, Vol. 10, No. 4

penchant towards a holistic approach to the problem of accounting valuations, and last, but at the same time first from a doctrinal point of view, the tendency toward a scientification of the discipline of financial accounting measurements.

Keywords: Accounting, Accounting history, Accounting valuations, Financial accounting measurements, Development of accounting thought, Italy

\section{Introduction}

The main subject of this paper is the theory of accounting measurements as observed from a historical perspective. In particular, the research concerns the most significant theoretical concepts developed by the Italian studies in the period from the 1920s to the 1960s; a period that was almost devoid of accounting regulation (Note 1). This period was a historical phase of great cultural ferment, characterised by the progressive deepening of the subject of accounting valuations by Italian scholars that was made possible, in some cases, by the careful observation of practise, and in others by their original intuitions. During this period, there were some very interesting theoretical positions that were, and still are, little known especially outside Italy.

The theorization on financial statement valuations developed in Italy between the 19th and 20 th centuries is not a new topic in international accounting history. Indeed, several accounting historians conducted studies on this issue. In 2011, Alexander and Servalli paid attention to the problem of financial statement valuations in the thinking of Gino Zappa and other influential Italian scholars within the multi-faceted scenario of the Economia Aziendale, by highlighting in particular the inconsistency of the theories developed by these authors, who were advocates of the flexibility in valuation criteria and a concept of income future-oriented, with the prevalent adoption of the historical cost principle in Italian financial practice. In the same year, Gonnella examined the doctrinal evolution from the criterion of exchange value to the one of historical cost, which took place in Italian studies between the Nineteenth and Twentieth centuries. Subsequently, the scientific dispute between Pietro Onida and Raymond Chambers dating back to the seventies of the last century was analyzed by Gonnella and Talarico (2017). This dispute arises from a different view about valuation criteria: Onida advocated the principle of 'different values for different information purposes', with the adoption of a plurality of measurement criteria within the same financial statement, while Chambers maintained the absolute neutrality of information and, consistently, of the use of a single measurement base, particularly the Current Cash Equivalent. A fundamental contribution to the study of the Italian doctrine on financial statement measurements was then provided by the book entitled 'The History and Tradition of Accounting in Italy', edited in 2017 by Alexander, Adamo, Di Pietra and Fasiello. Specifically, this book contains numerous contributions by Italian accounting historians on the subject at hand. Each of the twelve chapters is aimed at examining the thought of a single author or of several scholars of the same school (Note 2). A wide-ranging investigation ensues.

Unlike previous works, this paper carries out a longitudinal analysis of the thinking of some prominent authors who published their writings from the twenties to the sixties of the last century. The goal of this research is not so much to merely review the different theoretical positions but to understand the possible underlying tendencies in the evolution of these 


\section{MlMacrothink}

International Journal of Accounting and Financial Reporting

ISSN 2162-3082

2020, Vol. 10, No. 4

positions using an interpretative approach (Previts, 1990a, p. 2). This work is part of a series of studies on the development of accounting thought (Previts, 1990b).

The evolutionary process regarding the subject of financial accounting measurements found in the period under consideration was undoubtedly complex and articulated. Because it is impossible, within the limits of this paper, to analyse the thought of the many scholars that contributed to the development of the subject at hand, we deemed it appropriate to focus our attention on those scholars who, by developing theses considered to be among the most innovative and original in the field, left their mark on Italian accounting history. In particular, reference is made to such scholars as Gino Zappa (1879-1960), Vittorio Alfieri (1863-1930), Francesco De Gobbis (1863-1942), Pietro Onida (1902-1982), Lorenzo De Minico (1896-1949), Alberto Ceccherelli (1885-1958), Egidio Giannessi (1908-1982). This study is based on the analysis and comparison of the most significant writings of these authors, which are the primary sources of this research (Note 3).

The analysis of the different theories devised by the above-mentioned masters, which must be conducted within the limited length of this paper, led us to identify four logical steps in the evolution of the theories that were developed on the subject during the considered phase.

This paper also aims to provide greater international visibility to the theorisation under discussion and to these authors in an attempt to overcome the language barriers that limit the diffusion of some national disciplines, including Italian accounting, to English-speaking countries (Parker, 2003; Carmona, 2004).

Following this introduction, in Section 2, we briefly present some useful information for a contextualization of the topics being analyzed, mostly by focusing on the notion of azienda (Note 4) - developed in the field of Economia Aziendale [Italian Business Economics] - and on the particular function performed by financial statement in the Italian context of the time (Section 2.1); furthermore, we summarize the state of accounting regulation in Italy in the period considered (Section 2.2). In Section 3, we describe the 'state of the art' about accounting measurements in the early 20th century in Italy, in order to identify the 'starting point' of the subsequent theoretical development. Section 4 is dedicated to the main topic of the paper, namely the critique of the most significant theories on accounting valuations developed by eminent Italian scholars between the twenties and the sixties of the last century. Four different approaches to the accounting valuation problem will be identified which mark as many evolutionary phases of the theoretical development on the subject: 1) the thesis of the plurality of valuation criteria within the same financial statement, supported by Vittorio Alfieri (section 4.1); the thesis of the 'discretionary valuations' of the 'second' Gino Zappa (section 4.2); the thesis of the 'precautionary guiding principles', maintained by Francesco De Gobbis, Pietro Onida and Lorenzo De Minico (section 4.3); and, the thesis of the 'functional valuation', proposed by Alberto Ceccherelli and Egidio Giannessi (section 4.4). It is necessary to point out that the exposition of the various theoretical positions, which mark the evolution of thought on the subject under consideration, does not follow a rigid chronological order but precisely reflects more a logical sequence. In Section 5 we try to identify the main underlying tendencies in the examined development process. Concluding remarks are presented in Section 6. 


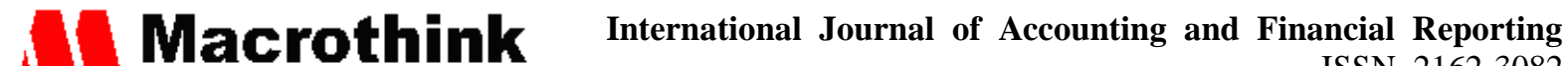 Institutem"

\section{Brief Notes About the Italian Context in the Period Examined}

\subsection{The Studies in the Fields of Economia Aziendale and Financial Accounting}

As regards the studies in the fields of accounting and Economia Aziendale, it could be useful to mention a few significant aspects for this investigation that concern the notion of azienda and the vision of financial statement in the Italian doctrine of the time. In the period at issue, Gino Zappa's studies started to spread (Zappa, 1920-1929 and 1927). Besta's paradigm was gradually replaced by Zappa's one (D’Amico, 1999, p. 41 ff.). By observing the ongoing changes, and particularly the increasing complexity of the manufacturing structures and operating processes of the larger firms, such as their progressive mechanization (Catturi, 1989, p. 132 ff.; Di Stefano, 1991), Zappa finally and consciously introduced in the Italian doctrine the systemic notion of the azienda (see Bertini, 1990, pp. 20-28; Canziani, 2013, p. 76), and said, about this:

'When closely observed, all the phenomena regarding the azienda ... appear established as a single coordination of economic actions aimed at achieving a specific goal. Perhaps this notion cannot be described more effectively than by using the notion of system ...' (Zappa, 1920-29, p. 330) (Note 5).

So, it is not by chance that Zappa was defined as the herald of a 'radical holistic approach' (Zan, 1994, pp. $288 \mathrm{ff}$.). By adopting this perspective, the scholar gave a better interpretation of the evolution of the azienda as a phenomenon and, by so doing, he pushed accounting researchers to consider the new needs that were arising in the field of accounting. This had two significant implications: the financial position was viewed as a 'fund of coexistent values', that is '... a whole that ... determines the quantity of parts ...' (Zappa, 1920-29, pp. 15 and 3) (Note 6); the principle of the unity of operations over time, as well as in space, by virtue of which each accounting period is linked to the previous and to the next, seamlessly (Zappa, 1920-29, p. 508). This, in our opinion, favoured the development of a systemic and dynamic interpretation of the financial valuation by Italian scholars at that time. Not surprisingly, it was subsequently pointed out that Economia Aziendale, and particularly the theory of the azienda, have provided a valuable framework within which we can build the interpretive processes implemented by accounting (see, inter alia: Zan, 1994; Viganò, 1998; Zambon, 1996; Zan and Zambon, 2000).

We should also add that, over the period considered, Zappa's studies contributed in Italy to progressively replace the static vision of financial statement, typical of the 19th century, with a dynamic notion (Alexander, Fasiello and Giaccari, 2017), in the same way as happened in Germany and in the United States (Buckmaster, 1997). The main purpose of the financial statements was no longer the determination of financial position, but the calculation of the period's income, a central theme in Zappa's vision (Canziani, 1994, p. 153; Galassi, 1996, p. 617), in order to explain, as accurately as possible, the formation of income itself. This is the aspect on which the attention of Italian accounting scholars progressively focused. So it was that, in Italy, the sistema patrimoniale (asset-based accounting), conceived by Besta, was gradually replaced by the sistema del reddito (income-based accounting) proposed by Zappa (Giannessi, 1969, p. 472). 


\section{MlMacrothink}

International Journal of Accounting and Financial Reporting

ISSN 2162-3082

On the other hand, in Italy the financial statement was conceived as a prevalently internal information tool (Viganò, 1998, pp. 394-395), with a 'private' nature, with a control function on operating trends and the duty to determine the result to be distributed, more than an external communication tool aimed at meeting public interest purposes (Poli, 1971, p. IX). Those were the years in which Accounting was seen as a discipline aimed at producing information suitable to meet the needs of management; in other words, a discipline mainly focused on the decision-making process (Antonelli and Sargiacomo, 2015, p. 124).

\subsection{The Accounting Regulation}

From the point of view of accounting regulation, we should highlight the peculiarity of the Italian model in passing accounting and reporting rules - a typically bureaucratic model, indeed (Note 7). In Italy, as in other civil law countries, said regulations are the result of the legislative activity of the State rather than the expression of the action of standard setters (Di Pietra, McLeay and Riccaboni, 2001). Particularly in the period considered, the financial statement was a subject initially regulated by the Codice di Commercio of 1882, and subsequently by the Civil Code issued in 1942.

In the 1882 Code of Commerce, the subject of financial reporting was dealt with in some articles in a rather brief and incomplete manner. Referring to limited companies, said code ratified the obligation for directors to prepare the financial statement (art. 176, paragraph 1) and required it '.. to demonstrate with evidence and truth (evidenza e verità) the actually realized profits and the suffered losses' (art. 176, paragraph 2). Furthermore, the Code established that it was forbidden to pay ' ... dividends to shareholders, unless on profits actually realized according to the approved financial statement' (art. 181, paragraph 1). The directors were personally liable to shareholders and third parties 'for the actual existence of the dividends paid' (art. 147, point 2). However, said indications were followed by no reference to specific valuation principles or criteria to be used to favour the achievement of the above-mentioned objectives. In this regard, the legislator had required companies only to indicate in the Articles of incorporation or in the Bylaws the standard to be complied with in '... preparing financial statements and calculating and distributing profits' (art. 89, paragraph 1, point 6). From this one can clearly infer that, although said regulations had been set forth, during the applicability period of said code (1st January 1883 - 21st April 1942), any valuation principle and criteria was fully lawful if compliant with the rules set forth in the Articles of incorporation or Bylaws. Hence, a wide margin of discretion remained for directors in preparing the financial statement (Coda and Frattini, 1986, p. $113 \mathrm{ff}$.).

When the Civil Code was issued in 1942, the subject matter of financial statement valuations was defined for the first time. In particular, with art. 2425, the legislator introduced some valuation criteria concerning specific assets: tangible and intangible fixed assets, inventory, shares, fixed income securities, account receivables (Note 8). These criteria, however, seemed to be rather generic (Faccipieri and Rullani, 1982, p. 113). In addition, one should note that said valuation rules still left a wide margin of discretion to directors, reinforced by the option to make exceptions to the regulations set forth for 'special reasons' (speciali ragioni), with the only obligation for them and for statutory auditors to justify the exceptions in their respective 
reports (Consorti, 2001, pp. 195-196). In the period examined, in substance, accounting regulation was developed only to a limited extent. Consider that, over the period at issue, Italian professional institutions - the Collegio dei Ragionieri (CNR, Board of Accountants), created in 1910, and the Consiglio Nazionale dei Dottori Commercialisti (CNDC, National Council of Chartered Accountants), created in 1953 - had not yet taken any interest in accounting regulation. It was only in the mid-seventies that said institutions would start to develop accounting standards by creating a specific commission for the purpose (Note 9). Also note that such a situation left a wide space to the development of theories by accounting scholars.

\section{The 'State of the Art' About Accounting Measurements in the Early 20th Century in Italy}

The theorisation in the field of accounting valuations showed significant development in Italy during the second half of the 19th century (see Gonnella 2012). Even then, several Italian scholars had contributed to the progress of the matter being analysed. In this regard, we can recall, among others, Francesco Villa (1870, pp. 1-58), Giovanni Rossi (1895), and Fabio Besta (1891, I, pp. 237-511; 1893, II, pp. 11-17). Faced with the need to properly develop the problem of accounting measurement, these scholars thought it appropriate to rely on concepts that belonged to similar sciences, such as economics and real estate appraisal, by blindly borrowing the theory of value - in the Schumpeterian sense (Note 10) - from the former and the theory of valuation from the latter. During this age, everything hinged on the concept of 'exchange value'. In accounting, the 'exchange value' was taken to mean a universal value, that is, a value that could fulfil any informative requirement of the balance sheet.

At the dawn of the 20th century, the scholars' attitude became more critical. The accounting scholars discarded, although by degrees, the idea of the existence of a 'true' or an 'actual value' (i.e. the 'exchange value'), by sensing the possibility that could there be multiple 'correct' values, depending on the purpose set forth for the valuation. Simultaneously, a first principle took shape, which is still the basis of the theory of accounting measurements, that has been called the 'finalistic principle of value' (Gonnella 2010, pp. 1260-1263). This principle lays down that different measurement criteria must be applied to different informative purposes. In other words, the informative purpose must inform the choice of a measurement method. Perhaps it would not be wrong to identify the enunciation of this principle with the birth of the theory of financial accounting measurement in Italy. An alternative criterion to that of the 'exchange value' thereby made its appearance on the scene of accounting measurementnotably, the historical cost method.

In the first decade of the last century, the Italian academic studies had thus achieved some important results. In this regard, it is worth mentioning the prevailing theses with reference to accounting valuations, in general, and to the more specific field of annual financial statement valuations.

With respect to accounting valuations in general, the fundamental idea that different valuation criteria should be applied according to the different informative purposes and the firm's status (going-concern vs. winding-up scenario) made its appearance (Besta, 1909, II, p. 11; 
Pantaleoni, 1904, pp. 205-211; Zappa, 1910, p. 27); this idea is the so-called 'finalistic principle of value'.

Regarding the more specific field of financial statement valuations, the following thesis were formulated:

1) The idea of using a single method of valuation within a single balance sheet was advocated to ensure homogeneous values within the same financial statement (Besta, 1893, II, p. 12; Besta, 1909, II, p. 11; Zappa, 1910, p. 28).

2) The doctrine took a firm position in favour of the application of the cost principle in its different shades, depending on the type of assets to be valued, as a general criterion for financial accounting measurements (Zappa, 1910, p. 74).

This was, in brief, the "state of the art" that Italian scholars faced in the early 1920s.

\section{Italian Studies About Accounting Measurements From the Twenties to the Sixties of Last Century}

\subsection{The Plurality of Valuation Criteria Within One Financial Statement: The Contribution of Vittorio Alfieri}

With Alfieri's work (1863-1930), which left its mark on the work of other excellent accounting scholars (Note 11), the subject of financial statement valuations is enriched by a new theoretical proposition. This scholar's argument takes its cue from the acknowledgement of a fact, i.e., that the principle of the uniqueness of the valuation criterion - theorised by Besta and Zappa, as well (see Gonnella 2012) - is sometimes hardly applicable to the real world. We will quote from his Ragioneria Generale (General Accounting), published in 1921: 'The different nature, the different origin, the different use of the assets that constitute the capital of a firm does not always allow a full and constant uniformity of valuations' (Alfieri, 1921, p. 58). The scholar then continues: 'If the cost of all assets were known or if the current price of all of them could be established, there would be uniformity of valuations. But such conditions very rarely happen'. In his later work Osservazioni intorno alle stime (Comments about Valuations) (1925), his argument would become even more explicit, when, speaking of financial statement valuations, he wrote: 'It is said that the assets should all be valued in the same way if one wanted to have truly homogeneous values, which is a prerequisite for adding them together, but not all of them involve the same valuation criteria!... Adopting different criteria is unavoidable ...' (Alfieri, 1925, p. 402; see also p. 398). With this assertion, he added that he welcomed the application of different criteria even within one financial statement, thus supporting the opposite argument to the generally accepted viewpoint. In effect, his argument was a radical innovation in comparison to the prevailing theories (Anselmi, 1984, p. 35). The valuation of the different assets, as highlighted by the scholar himself, requires that the assets be divided into several groups. In this regard, Alfieri writes, the valuation needs '...dividing assets into the following classes: a) assets that may be valued on the basis of market prices; $b$ ) assets that may be valued on the basis of income; and c) assets that may be valued on the basis of costs' (Alfieri, 1925, p. 398). This division must occur because, in his view, '... market-price-based valuations, income-based valuations and cost-based valuations must often 
support each other' (Alfieri, 1925, p. 401) (Note 12). With this statement, the scholar's position on this issue is clear: from Alfieri's perspective, assets are valued by dividing them into different classes, each one matched to a different valuation criterion or, if one prefers, by rationally selecting the most appropriate criterion for each asset. Unlike some of his contemporaries, Alfieri did not issue any guideline that could help accountants select a different valuation rule that was applicable to each asset, but rather he issued a general appeal to the sense of measure: '.. the plurality of criteria - I quote - does not make the valuation less valuable if one rejects, as prudence would dictate, any exaggeration, and if one wisely stays halfway between optimism and pessimism at all times ...' (Alfieri, 1925, p. 403).

In other words, with Alfieri, the subject of accounting valuations gains a new theoretical principle, i.e., that of the plurality of valuation criteria in one financial statement. So we will have different valuation criteria, depending not only on the different informational purposes pursued, an argument that back then was already widely accepted (Note 13), but also depending on the different qualities of the assets to be valued.

In conclusion, Alfieri's contribution appears to deserve special attention not only because it leads to a more aware and mature valuation theory but also because he adds elements of relativity to the subject of valuation, elements that foreshadow and pave the way to more sophisticated theories on financial statement valuations.

The distinctive traits of this first stage can be summed up as follows:

- A plurality of valuation criteria in one financial statement, an option that had been expressly denied by Besta and Zappa, is now accepted.

- A theory of valuation consisting of a rational selection of the criterion to be applied on a case-by-case basis to each asset is formulated.

\subsection{From Valuation Criteria to Discretionary Valuations: The 'Second' Gino Zappa}

With the publication of the second issue of his La determinazione del reddito nelle imprese commerciali (Income Determination in Commercial Enterprises) in 1929, Zappa returns to the subject of financial statement valuations, systematically revising his initial position as proposed in Le valutazioni di bilancio con particolare riguardo ai bilanci delle società per azioni (Balance Sheet Valuations with Particular Reference to the Financial Statements of Joint Stock Companies) (1910) and in the first part of the above-mentioned work (Note 14). On this subject, as well as on other fundamental accounting subjects and on business administration in general, he moves towards conceptual positions that reflect a significant maturation of his thought.

In the section concerning 'Inventory valuation' (Zappa, 1920-29, pp. 599-615), Zappa starts his reflections by firmly criticising the cost-based criterion, as well as the 'petty rule', as he called it, of the lower of cost or market value. A few years earlier, he had, in fact, been a staunch supporter of this rule. What are the reasons behind his radical change of perspective?

'Maybe even in these last few years...' Zappa writes, firstly, in the aforementioned section, 'the belief in the logical certainty and the practical usefulness of the valuation of inventory 


\section{$\triangle$ Macrothink}

International Journal of Accounting and Financial Reporting

ISSN 2162-3082

2020, Vol. 10, No. 4

based on cost became more widespread than in the past' (Zappa, 1920-29, p. 599). In fact, it would be a 'careless naivety', in his opinion, to believe '... that cost accounting may be essentially reduced to a statement of incontrovertible facts that can be concretely verified ...' (Zappa, 1920-29, p. 601; see also p. 599). There is no doubt that these positions go entirely against those that he had advocated in his earlier writings. However, this will not surprise a careful reader if it is true that the scholar, a few pages earlier and with an uncommon sense of self-criticism, had already used a reverse quotation from his Valutazioni di bilancio to corroborate the argument antithetical to his previous opinion. In this passage, appropriately revised by adding the negation 'not' before the passage written years earlier, he notes that '... the cost of products... may not "be generally determined, if not with perfect accuracy, with great approximation, provided one keeps appropriate bookkeeping systems and follows cost formation in its different times"' (Zappa, 1920-29, p. 563) (Note 15). This is because, as he carefully explains, the combinations of cost can be of various types (Zappa, 1920-29, pp. 601-602), as can the assumptions that costing is built on (Zappa, 1920-29, p. 614). To draw a conclusion about this first issue, i.e., the uncertainty that is innate to the calculation of cost data, it might be helpful to quote the passage with which Zappa ends his reflections on this issue: '... that the valuation of inventory based on prime cost is the only rational one... is what nobody will ever manage to prove due to the frequent uncertainty of such prime costs ... and due to the wide variety of the firm conditions and market trends' (Zappa, 1920-29, pp. 604-605).

There is a second point to be investigated. Zappa, apart from the aforementioned criticism, raises a very interesting question as to whether ' ... prime cost... ... [can] be an exceedingly small part of the manufacturing cost for the deferral of costs to be necessarily limited to it' (Zappa, 1920-29, pp. 602-603). This issue is particularly awkward because, as is clear, it concerns the division of the estimated income from operations in progress at the end of the accounting period over different financial years. The scholar's answer is that ' $\ldots$ deferring the registration of results and allocating them entirely to that financial year in which every operation is perfected is not always possible or helpful ...' (Zappa, 1920-29, p. 603). That is why, then, in some cases, the option to value inventories at an 'estimated current exchange price' (Zappa, 1920-29, p. 605) (Note 16) or at 'estimated revenue' should not be ruled out (Zappa, 1920-29, p. 608) (Note 17).

Truth to tell, the criticism brought by Zappa against the then prevailing view regarding financial statement valuations appears to be far deeper and wider in scope because it appears to touch on the very foundations of the valuation logics. Actually, by breaking from the traditional patterns with his new approach, Zappa can be said to have rejected the use of rigid valuation rules, that is, the mechanical application of valuation criteria or of this or that value. Prompted by the consideration, repeated on several occasions, that inventory valuation - an operation of which he clearly perceives the unique complexity - is essential '... to separate between two accounting periods the [estimated] results of operations that have not been fully perfected yet' (Zappa, 1920-29, p. 605), he firmly moves in the direction of finding an innovative solution to this problem, and he proposes the so-called 'discretionary valuation procedures' (Zappa, 1920-29, p. 609). In the 'second' Zappa, then, accounting valuation is no longer based on one specific valuation criterion or one specific type of value but on a 
judgement that is partly prompted by an analysis of the internal and external operating conditions (Zappa, 1920-29, p. 605). Here is the point: according to the scholar, ' $\ldots$ the inventories... must be generally estimated at a value that has its limits in costs and assumed revenues but that may not be defined other than on a case-by-case basis, in connection with a wide and variable range of business and market circumstances' (Zappa, 1920-29, p. 608; see also: p. 606) (Note 18). Zappa, therefore, suggests using reasoned values, which involve an in-depth analysis of the income-formation process in an attempt to rationally divide the estimated results from operations in progress at the period end among the subsequent financial years.

That said, it is clear that the methodological solution proposed by the scholar might allow earnings management as well as the recognition of merely expected profits. Zappa himself highlighted this risk when he wrote that the proposed method 'universally accepted by experts', on the one hand, '.. is a method that frequently contributes to income smoothing' (Zappa, 1920-29, pp. 606-607) and, on the other, '... may constitute a method for the 'advanced recognition of profits' in a covert manner' (Zappa, 1920-29, p. 609). Regarding the second issue, it would be helpful to note that the 'new' Zappa welcomes, in principle, the above-mentioned anticipation, although he is aware that, in doing so, he is advocating a thesis that goes against the tide (Zappa, 1920-29, p. 609). The advance registration of profits deriving from ongoing operations actually disregards the revenue recognition principle, generally accepted by the Italian authors even back then, that he had supported himself in his early work 'Valutazioni'. Zappa, however, aware that 'theories... owe it to facts ...' (Zappa, 1920-29, p. 320 ) argues the new thesis by drawing safety from the behaviours observed in practise. So the author, after illustrating some examples from reality in which unrealised profits are recognised in income (Zappa, 1920-29, pp. 610-614), concluded that 'even when the sale has not been executed yet or has not been negotiated yet, usually, through the inventory valuation, practice recognises in income a part of the estimated 'profit' or 'loss' ' (Zappa, 1920-29, p. 612). But, in his opinion, the 'advanced recognition of profits' requires due caution; in particular, this recognition '... may not be accepted but when one can safely rely on the sale and the realisation of revenues, at least on well-founded assumptions' (Zappa, 1920-29, p. 612). After all, the scholar did not miss the fact that even historical cost valuation cannot, by any means, rule out the advance recognition being discussed (Zappa, 1920-29, pp. 613-614).

Lastly, it is appropriate to quote from a passage that appears to best summarise Zappa's new approach to financial statement valuation. 'Rather than the vain search,' Zappa writes, 'for impossible procedures that might give unquestionable certainty to the results of coordinated and in-progress operations, even in this respect one may be helped by the deliberate awareness of the many difficulties that the problem poses and a thorough analysis of the methods that, in real and different circumstances, help solve it in different ways' (Zappa, 1920-29, p. 614).

The main distinctive traits of the above-mentioned moment can be summarised as follows:

- Criticism of the historical cost valuation method and of the use of inflexible valuation rules in general. 


\section{MInstitute Mach $^{m}$}

International Journal of Accounting and Financial Reporting

ISSN 2162-3082

2020, Vol. 10, No. 4

- Statement of 'discretionary valuations' based on a judgement that is partly built on an analysis of the firm's situation and external market conditions.

- The introduction of 'valuative reasoning' in the theory of accounting valuations, replacing the application of specific valuation criteria, which promises further developments in a scientific direction.

\subsection{Precautionary Guiding Principles: Francesco De Gobbis, Pietro Onida, Lorenzo De} Minico

With the contributions of Francesco De Gobbis (1863-1942), Pietro Onida (1902-1982) and Lorenzo De Minico (1896-1949), the theory of financial accounting measurements makes another step forward, adding a guiding principle that is suitable for informing the assignment of financial statement values. Supporters of the argument of multiple valuation criteria in one financial statement (De Gobbis, 1925, p. 129; Onida, 1935, pp. 68-70; De Minico, 1935, p. 291), the three scholars propose some precautionary guiding principles (see Amodeo, 1938, pp. $28-41 ; 1955$, pp. 20-25) to avoid excessive valuations in their entirety, that might somehow undermine a firm's own life (Note 19). In other words, they want to oppose the unjustified overestimation of net income and, therefore, the distribution of sham earnings that could subtract useful resources from the future operations of a firm.

One first precautionary principle is worded by De Gobbis in his monograph on Bilancio delle società anonime (Financial Statement of Limited Companies), published in 1925; this principle was defined years later by De Minico as the 'non impairment owners' equity' (1935, p. 340, note). Notably, assuming that '.. the changeability of the valuation criteria applied to one single balance sheet... shows no uncertainty nor contradiction or arbitrariness but constitutes ... the application of a supreme principle of wise, conservative, prudent administration ...', he states clearly that '...valuations must be made to avoid a distribution of earnings that may be or may turn de facto into an impairment of the capital stock and the retained earnings in the past ...' (De Gobbis, 1925, p. 129). According to the scholar, an essential requirement of balance sheet valuations is protecting the integrity of net assets and with it, as Amodeo would eventually explain (Note 20), the firm's profitability. As a supporter of this argument, De Gobbis develops a precautionary theory to provide directors with a guideline to help them draw up the financial statement. The 'supreme criterion' that he hints at is but a general assertion, a veritable scientific principle that helps to raise the subject of valuations from a technical-regulatory level to the scientific level of accounting (Note 21).

Ten years later, in 1935, with the establishment of the 'new trends' proposed by Zappa (1927) (Note 22), two more principles, based on an income view, find their place next to the aforesaid asset-based informative principle, which is based on a capital view. In other words, attention is shifted somehow from capital to income, even if the differences - as it was explained back then (see De Minico, 1935, pp. 294-295, no. 1 and pp. 339-340, no. 1; Amodeo, 1938, p. 30, no. 24) - are more formal than substantial in nature. Thus, here is Onida's principle of non-impairment of future incomes, contained in his monograph on Bilancio delle aziende commerciali (The Financial Statement of Business Enterprise) (1935), where the scholar notes that 'in its typical and ideal configuration ... net income.... would be ... the greatest value up to when one has a 


\section{$\triangle$ Macrothink}

International Journal of Accounting and Financial Reporting

ISSN 2162-3082

2020, Vol. 10, No. 4

profit and dividends might be allocated or income might be taken ... without undermining or damaging ... the net incomes of the subsequent accounting period ...' (Onida, 1935, p. 56; see also p. 59). Here is then, again, De Minico's principle of protection of the normality of future incomes, as can be found in his book Elasticità e relazioni dinamiche dei costi delle imprese industriali (Elasticity and Dynamic Relations of Costs in Industrial Enterprise) (1935), according to which 'the need for caution and prudence in maintaining at least a normal future stream of income guides and inspires the rules for valuing the financial position at the end of the financial year and therefore the allocation of income to such a financial year' (De Minico, 1935, p. 291). It might be helpful to notice, although incidentally, that De Minico's arguments would find their natural development within the Neapolitan School of Accounting and the theory of the limit value of 'economic capital' (i.e., firm's equity value), which sets a maximum threshold for the financial position (see Amodeo, 1943, p. 137; Salzano, 1938, pp. 114-117) (Note 23). In this approach, the former is basically a way to test the latter. Returning to our main point, we can conclude that Onida and De Minico, as can be easily guessed from the above passages, enunciated in the same year theoretical principles that share the protection of future profitability and, with it, the protection of the firm's own life (Note 24). This thesis, despite appearances, is comparable to that of De Minico's predecessor De Gobbis.

With the introduction of the protective principles, the theory of financial accounting measurements is not only enriched with new contents, it is also raised to a more scientific level (Note 25). Two aspects are noteworthy.

The first element to be taken into account is undoubtedly the fact that, with the precautionary principles, Italian accounting scholars eventually develop some genuinely scientific propositions. Actually, these are not merely prescriptive rules, but guidelines that are capable of guiding the directors in allocating income to a financial year, which on a doctrinal level can only provide more scientific weight to accounting (Note 26).

Then, there is an additional point that appears extremely important. Specifically, the precautionary principles establish a first overview of the problem of financial accounting valuations. The valuation process, which until then had been carried out by valuing each asset in an autonomous manner, finds a final moment of synthesis that can sometimes result in a more or less substantial revision of the initially assigned values. This change of perspective is clearly dramatic, on both the theoretical and the operational levels. Through such principles, in financial statement valuations, the atomistic logic which had prevailed until then is now being surpassed by a systematic interpretation of the problem. Onida's words are the most telling in this respect when, in the second edition of the aforesaid work, he notes that '... a final judgement on the usefulness of accepting (or not accepting) the estimated value assigned to income or capital components cannot clearly be passed until such components are isolated and individually analysed outside the system they belong to' (Onida, 1940, p. 74; see for examples pp. 74-75). In this way, a first systemic view of financial statement valuations emerges, which kick-starts the typical approach of the Italian accounting school, i.e., the so-called 'valuative holism'. Once an aggregate of values, the financial statement now tends to look like a veritable 'system of values' (Onida, 1940, p. 74). After all, the scientific stature of the above-mentioned precautionary principles appears to find its logical preconditions in a systematic approach to 
the valuation problem. This point is also addressed by De Minico when he notices that the 'valuation of capital looks like a scientific problem only if it is taken as a unitary valuation extended to every business area because only in this case can there be that essential point of reference that is the future net income of the business' (De Minico, 1946, p. 247).

The distinctive traits of the above-mentioned phase can be summed up as follows:

- A precautionary information principle is added to the plurality of criteria in one financial statement and to the attendant principle.

- The theory of accounting measurement becomes more scientific through the addition of a general guiding principle.

- A first systematic view of the problem of financial statement valuations is established.

\section{4 'Functional Valuation': Alberto Ceccherelli and Egidio Giannessi}

So, we arrive at the last logical stage of the historical period analysed, the period related to the thought of Ceccherelli (1885-1958) and Giannessi (1908-1982).

In his work Il linguaggio dei bilanci (The Language of Financial Statements) that was first published in 1939, Ceccherelli introduces the concept of the 'degree of functionality' of assets and the ensuing concept of 'functional value' (Ceccherelli, 1939, p. 192), although with reference just to a limited part of the capital, that is, the non-financial assets (Note 27). According to the scholar, '....assets... have a specific, essential function and... that's why they were bought...' (Ceccherelli, 1939, p. 189). Again, in his opinion, these components '... do not have an independent position in the capital of the firm: they exist usefully, since they contribute, along with others, to making a given type of economic transformation possible; in other words, they compose a whole, which is bound to and dependent on the firm's operations' (Ceccherelli, 1939, p. 189). As such, assets are complementary productive resources, not autonomous goods (Note 28).

With that statement, here is Ceccherelli's successful intuition: the purpose of financial accounting valuations is to '... translate into a value the functional qualities of the firm's assets ...' qualities that '... sum up the capacities and productive potentials of the [aforesaid] assets ...' (Ceccherelli, 1939, p. 196) (Note 29). In Ceccherelli's view, the assignment of values at the end of the financial year requires an analysis of the operating capabilities of the various assets, these latter being considered not individually but rather as parts of a whole.

These functional qualities, at the time the asset was bought, necessarily '.. find their quantitative expression in the original cost ...' (Ceccherelli, 1939, pp. 196-197; see also 192-193); later on, when internal and external conditions change, their quantitative expression appears in the cost that '.. at such time is the expression of the new degree of functionality ...' (Ceccherelli, 1939, p. 195). Therefore, the valuation process consists in changing the original cost according to the new productive capacities of these components (Note 30). This statement is easier to understand if we note that, according to Ceccherelli, "valuing the capital ... does not mean... assigning values to the different groups or qualitative units that compose it; it means, instead, assigning a value to what is left over of the original costs and the subsequent costs 


\section{MlMacrothink}

International Journal of Accounting and Financial Reporting

ISSN 2162-3082

2020, Vol. 10, No. 4

incurred to operate the firm' (Ceccherelli, 1939, p. 190). One should not believe, though, that he proposes to adopt the cost-based principle. It is not so. When he speaks of this principle, he hastens to note that it is merely a guiding principle (Note 31 ).

There might be many more passages worth mentioning, but those presented herein appear to be adequate to demonstrate an aspect of Ceccherelli's theory that is particularly interesting for the purposes of this paper. In Ceccherelli's thought, valuation consists not so much of the mere application of a valuation criterion, a simple estimate rule, even if it is the most appropriate to the case. Instead, valuation is a veritable logical reasoning that is grounded - here lies his innovative contribution, in my opinion - on the analysis of the functional qualities of a given productive factor. Ceccherelli's thought actually revolves around the concepts of functional qualities and the degree of functionality, as well as in the ensuing concept of functional value.

Later on, Giannessi, in his work on Le aziende di produzione originaria - Le aziende agricole (Primary Sector Firms - Agricultural Firms) published in 1960, draws inspiration from the lessons of his teacher Ceccherelli. In this work, Giannessi manages to further explain the concepts of functional value and functional valuation, which he viewed as '... the most significant expression of the valuation process' (Giannessi, 1960, p. 598). In Giannessi's view, 'the valuation process involves the determination of the concept of functionality', in the awareness that it '... identifies the position of each factor within the firm's economic combination' (Giannessi, 1960, p. 67). That explains why, in his opinion, '... the functional values summarise [precisely] the position of productive factors within the firm's economic combination' (Giannessi, 1960, pp. 738-739). Therefore, valuing means understanding the economic capacity of each production factor within the operating structure that it belongs to. This point is central in the scholar's work, which appears to find its logical grounds in the research conducted first by his master, Ceccherelli, and extended by Giannessi into the modes for combining productive factors. According to Giannessi, productive factors are useless to a firm if they are individually considered (Note 32). Productive factors become useful only if they are appropriately combined (Giannessi, 1969, p. 513). However, the scholar did not merely put these considerations into words, although interesting in itself; he did more than that. Moving from facts to their representation - in other words, from business economics to accounting - he managed, following in his master's wake, to bring these conclusions to the level of accounting values, pointing out that 'two factors having the same nature may have different values, depending on the firm they belong to and the particular time at which such valuation is conducted' (Giannessi, 1960, p. 591). As we will see subsequently, the actual essence of the functional value lies precisely in the complementary nature of production factors.

One could state, at this point, that all of Giannessi's work is imbued with the notion of functional ability, a concept that, as he wrote himself, '... enables one to allocate a "functional value" to different balance sheet items' (Giannessi, 1960, p. 67). So it happens that, as the author himself notes, ' $\ldots$ in a functional valuation, the problem is based on the determination of the degree of connection with which each factor is bonded to one another; all together, they are bound to the system they belong to ... ' (Giannessi, 1960, pp. 603-604). At this point, the need is felt to understand the development of Giannessi's valuation process. 


\section{Mll Macrothink}

International Journal of Accounting and Financial Reporting

ISSN 2162-3082

2020, Vol. 10, No. 4

The scholar divides the valuation process into three stages, in which the functional value is perfected through subsequent approximations. At first, according to the scholar, '... one must identify the nature of the assets' (Giannessi, 1960, p. 591) to assign some initial values. Then, 'the assets must be related to the firm's system that they belong to' because 'value, in a firm's context, is not only based on the nature of the assets but also on the function they serve, as factors, within the productive combination'; this '.. is enough to change the originally-assigned values' (Giannessi, 1960, p. 591). Finally, 'once the firm value of assets has been established... such value must be related to the positions of equilibrium and the distinctive traits of firm dynamics' (Giannessi, 1960, p. 591). At this final stage, these values will change again because the potential use of the productive factors changes according to the type of equilibrium that is expected. So, these functional values, the final result of the valuation process, will be higher in the case of equilibrium and the evolutionary dynamics of firms and lower if the opposite is true (Giannessi, 1960, pp. 591-592). Saying that, we can conclude that the functional value of the balance sheet items is affected by three factors: 1) the intrinsic features of the considered component; 2) the ways in which it relates to the other components, forming altogether a productive combination; and 3) the economic-financial equilibrium conditions that characterise the firm.

A first conclusion that can be drawn from the above-quoted passages is that, according to Giannessi, valuation is a logical operation that goes beyond any mechanical application of a valuative criteria. After conducting a thorough study of the functional value of productive factors and extensively discussing the causes from which the value originates, in the wake of his teacher, he outlines a path to be followed in conducting financial statement valuations. The development, as it were, of a guiding idea that is suitable for directing the functional valuation process enables Italian accounting to progress consistently on a scientific level and to conduct more logical and conscious valuations on an operational level.

One further point that deserves special attention is that, with the concepts of value and functional valuation developed first by Ceccherelli and then by Giannessi, the complementary nature of the productive factors finds its full expression in the financial statement (Note 33). It is true that, while the authors had already mentioned the joint nature of the productive factors (Note 34), this nature had found no expression in the context of valuations except in precautionary theories. In functional valuation, one can certainly find a different expression a more explicit expression of the relationship between the complementariness of the productive factors and the going concern values. This aspect has led some more recent scholars to stress that the functional value has per se a relational character (see Corticelli, 1981, p. 95). Once again we find, although in a different guise than that of 'precautionary guiding principles', the systematic approach to financial statement valuations.

Another aspect worth mentioning is Giannessi's explanation of a valuation as a logical operation that relies on the formulation of an authentic valuative judgement, built on the analysis of an appropriate information basis. Actually, similar assumptions had already been perceived in Zappa's thought. However, here, the problem takes a more explicit and general tone. In other words, this means developing a valuation on the basis of a system of judging elements that concern the key aspects of business and environmental conditions. A judgement 


\section{$\triangle$ Macrothink}

International Journal of Accounting and Financial Reporting

ISSN 2162-3082

2020, Vol. 10, No. 4

of value sums up all of the information available, although differing from this information. Giannessi writes: 'The functional principle uses all historical and market information available but does not coincide with any of it' (Giannessi, 1960, p. 709). This statement is certainly not isolated because other ones to the same effect resound in many passages from his books (Giannessi, 1960, p. 709). This statement is indeed the recurring theme of all of Giannessi's valuation theory. It therefore makes sense to try to discover what role the valuation criteria play in the valuation theory that we are talking about. We could answer that the criteria lose their status as valuation rules and, along with other types of information, become elements of judgement that are at the source of functional valuation. Giannessi stresses this aspect on several occasions (Note 35). It should be noted, however, that Giannessi was not unaware of the utility of the historical cost, the replacement cost, the net realizable value or other values taken from the market, but it means that they are not identified as functional value, but rather as simple elements required for a judgement on the formulation of the functional value. What is missing, in the end, is a direct link between value and economic transaction, which is typical of other valuation theories (see Lee, 1998, p. 26), precisely because the functional value is peculiar to each azienda and to the conditions of its dynamics. In fact, the functional value has a special feature: unlike other types of values (e.g. historical cost, current cash equivalent, etc.) it does not immediately refer to a real or assumed economic transaction, but stems from a firm-specific valuation (Whittington, 2010, pp. 106-107; Barth, 2010, pp. 123-124). It is a value-in-use estimated as a function of the usefulness of the productive factor for the considered azienda. Being an entity-specific valuation, which also reflects the expectations, the assumptions and the intentions of directors (see: Barth 2006), functional valuation is strongly affected by the 'personal equation' of the preparer of the financial statement, and consequently it can be more easily manipulated. And, for the same reason, it is more difficult to audit.

There is one last consideration. With due caution, we believe we can say that with Giannessi, the theory of functional value is studied in depth and gains new content for two basic reasons: it is extended to all capital and therefore to the different types of assets that belong to it, and the theory makes reference to the firm's equilibrium. It is undeniable that the functional value from Giannessi's perspective, on the one hand, is a concept that no longer refers solely to the non-financial assets but, through a process of generalisation, concerns the financial assets as well and, on the other, goes beyond the mere firm value of assets, which already expresses the complementary relationship between different productive factors because it also reflects the firm's state of equilibrium.

To sum up, the step we have described so far is prominent for the following aspects:

- By working on the underlying causes of the value of the firm assets, the principles of value and functional valuation are developed.

- A systematic view of the problem of accounting valuations is developed that differs from the view embodied by the precautionary principles and that emphasises, in particular, the complementariness of productive factors.

- Accounting is enriched by a further general principle, which makes the discipline grow in its more scientific dimension. 


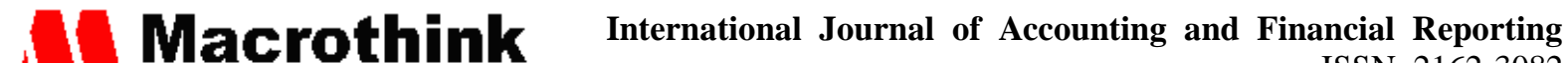 ISSN 2162-3082 2020, Vol. 10, No. 4}

\section{Underlying Tendencies in the Evolutionary Process Analysed}

Because of its purpose, this research cannot be limited to a mere review, no matter how critical, of the aforementioned theoretical positions. The time has come, therefore, to draw first conclusions, although with due caution and the necessary circumspection.

This analysis revealed how Italian scholars, aware that the valuative problem could not be addressed with simple valuation rules, were interested in finding general principles that could be useful models of behaviour for accounting practise, principles that would still retain a good explanatory power of the analysed problem. This made it possible to understand that the valuation, being a process that transcends the simple mechanistic application of predefined rules, requires the formulation of a judgment based on the observation of the firm's specific characteristics and of the external environment in which it operates.

The research also allowed the main trends in the examined evolutionary process to be identified.

A noteworthy aspect that appears to be suggested by this analysis is first and foremost a tendency during this period of time to a progressive relativisation of values. Through their relentless theorisations, the scholars, aware that there are no absolute truths but only relative truths in the area of accounting measurement, were looking for increasingly rational measurement approaches. The relative nature of financial statement values became apparent first in connection with the nature and state of each asset and liability, then also in connection with specific firm dynamics. This tendency came to the fore when, with Besta and the 'early' Zappa, the idea of the existence of an absolutely 'true value' that could fulfil any informative requirement disappeared. During the analysed period, this tendency became stronger, step by step, in connection with the specific area of accounting measurements, first during the transition from a single criterion, with Alfieri, to a plurality of measurement methods and then, when value had to be linked through different solutions, to corporate dynamics. The latter transition concerns the linking of values to corporate and market situations, which are mentioned by the 'later' Zappa, to the future earnings capacity implicitly referred to by De Gobbis and explicitly by Onida and De Minico, to Ceccherelli's functional qualities, and finally to Giannessi's modalities of the combination of productive factors and firm equilibrium.

In addition, as shown by the sequence of theories under investigation, there is a tendency toward an increasing subjectivity of values. With the introduction of the 'reasoned values', the degree of subjectivity in operational measurements and, accordingly, in the values that result from them, tends to increase. The subjective component, which is inherent in every type of valuation (Note 36) becomes stronger, first with Alfieri's introduction of the plurality of measurement criteria within one financial statement in lieu of the single method suggested by Besta and by the early Zappa, and then as the multiple measurement criteria lose their status and become elements of judgement in reasoned measurements. The latter case refers as much to Zappa's discretionary measurement processes as to Ceccherelli and Giannessi's functional measurements.

There is one additional trait that appears to be suggested quite clearly by this theoretical survey: 
the tendency toward a holistic view of the valuation problem. This concept became particularly widespread with the transition from the atomistic measurement approaches, in which every element (regardless of the adopted measurement principle) is independently measured, to the systematic approaches, whereby each component is measured as a part of a whole, that is, by taking into due account any complementariness. The financial statement therefore shifts from being a sum of independent values, as it used to be, to becoming a 'system of values'. This approach is new and typical of the Italian accounting school, which is embodied by the so-called precautionary principles, as theorised by De Gobbis, Onida and De Minico, as well as by Ceccherelli and Giannessi's functional measurements.

Finally, we would like to touch on one last aspect, which is perhaps the most important aspect from a doctrinal point of view, i.e., the tendency toward a scientification of the discipline of accounting valuations. The above observation of the evolutionary process showed that during these years, the Italian doctrine felt the need, within the area of accounting measurements, to elevate the study from the initial discussion of technical-dogmatic rules (e.g., the lower of cost or market method) to the later development of true general principles. It is for this reason that, through the efforts of the masters of Italian accounting, the latter have progressively been built around the former. The more mature theoretical positions have actually led to the enunciation of general principles, such as, for example, the 'discretionary measurement processes', the so-called 'precautionary principles' and the 'functional measurement principles'. So, the subject has grown scientifically and, given the role that it plays in the discipline, Italian accounting as a whole has grown as well.

We believe that the contribution of the theories formulated by scholars to the doctrinal growth of the Italian accounting is undeniable, although such theoretical construct did not directly lead to changes in accounting regulation and practices (see Alexander and Servalli 2011).

We believe that the doctrinal growth of Italian accounting that characterized the period examined is undeniable, although the theories conceived at the time have only had a limited impact on developing of accounting regulations and practices (see Alexander and Servalli, 2011) (Note 37).

\section{Concluding Remarks}

The evolution of accounting valuations in the period from the 1920s to 1960s was no doubt quite complex and intricate and, above all, full of innovative concepts that concurred, one after the other, to raise the scientific threshold of the time. In particular, Italian accounting managed to investigate the matter at hand from a scientific perspective.

The period analysed was a historical phase of great cultural ferment, when Italian accounting scholars increasingly explored the accounting measurement principles, which sometimes relied on the careful observation of the measurement practise and other times on the uncommon intuitions of brilliant authors. If one wanted to summarise the different stages in this process in a logical rather than a strictly chronological order, the stages might be identified as follows: 1) plurality of valuation criteria within one financial statement is theorised; 2) discretionary valuation processes are developed; 3) so-called precautionary principles are enunciated; and 4) 


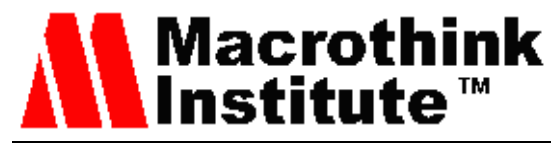

International Journal of Accounting and Financial Reporting

ISSN 2162-3082 2020, Vol. 10, No. 4

the 'functional valuation principle' is conceived. While the picture that we can draw from this evolution adequately proves the progressive extension and refinement of the theoretical grounds of accounting valuations, it gives prominence to the thorough, intensive research work that was carried out. After all, this work is no surprise given the key purpose served by this subject in accounting (see Alfieri, 1918, p. 64; Zappa, 1920-29, pp. 80-81).

The main trends in the examined evolutionary process include the progressive relativisation as well as the increasing subjectivity of values, the penchant towards a holistic approach to the problem of accounting valuations, and last, but at the same time first from a doctrinal point of view, the tendency toward a scientification of the discipline of financial accounting measurements.

\section{References}

Adamo, S., Di Cagno, P., \& Imperiale, F. (2017). Paolo Emilio Cassandro and the rational valuations. In Alexander, D. et al. (Eds.), The History and Tradition of Accounting in Italy. London: Routledge.

Alexander, D., \& Servalli, S. (2011). Economia Aziendale and Financial Valuations in Italy: Some Contradictions and Insights. Accounting History, 16, 291-312.

Alexander, D., Fasiello, R., \& Giaccari, F. (2017). Income measurement and asset valuation under Zappa's theory. In Alexander, D. et al. (Eds.), The History and Tradition of Accounting in Italy. London: Routledge.

Alfieri, V. (1918). Le regole, le classificazioni ed i concetti filosofici nelle opere italiane di ragioneria. Rivista Italiana di Ragioneria. Roma, marzo, n. 3.

Alfieri, V. (1921). Ragioneria generale (4th ed.). Milano: Società Editrice Dante Alighieri.

Alfieri, V. (1923). Le rilevazioni amministrative. Rivista Italiana di Ragioneria. Roma, n. 7.

Alfieri, V. (1925). Osservazioni intorno alle stime. Rivista Italiana di Ragioneria. Roma, n. 9.

Amaduzzi, A. (1939). Aspetti di problemi di valutazione nelle imprese commerciali. Padova: Cedam.

Amaduzzi, A. (1947). Conflitto ed equilibrio di interessi nel bilancio dell'impresa. Bari: L.U.C.E.

Amodeo, D. (1938). Contributo alla teoria delle valutazioni nei bilanci d'esercizio. Napoli: Italia Imperiale.

Amodeo, D. (1943). Di alcune posizioni limite nel campo di una teorica generale dei sistemi. Rivista Italiana di Ragioneria. Roma, n. 8-9-10.

Amodeo, D. (1955). Intorno alla teoria generale del bilancio di esercizio delle imprese. Napoli: Giannini.

Amodeo, D. (1965). Ragioneria generale delle imprese (2nd ed.). Napoli: Giannini. 


\section{$\triangle$ Macrothink}

International Journal of Accounting and Financial Reporting

ISSN 2162-3082

Andrei, P., \& Corbella, S. (2017). The contributions of Carlo Masini to accounting theories. In Alexander, D. et al. (Eds.), The History and Tradition of Accounting in Italy. London: Routledge.

Anselmi, L. (1984). Le valutazioni nel pensiero di Vittorio Alfieri. Pisa: Edistudio.

Antonelli, V., \& Sargiacomo, M. (2015). Alberto Ceccherelli (1885-1958): Pioneer in the History of Accounting Practice and Leader in International Dissemination. Accounting History Review, 25, 121-44.

Azzali, S., \& Fornaciari, L. (2017). The contribution of Lino Azzini to Financial Accounting and Group Accounting in Italy. In Alexander, D. et al. (Eds.), The History and Tradition of Accounting in Italy. London: Routledge.

Barth, M. E. (2006). Including Estimates of the Future in Today's Financial Statements. Accounting Horizons, 20, 271-285.

Barth, M. E. (2010). Comments on panelists. Abacus, 46, 120-127.

Bergamin Barbato, M. (2007). Tendenze nuove negli studi di Ragioneria. Contabilità e cultura aziendale. Roma, n. 1.

Bergamin Barbato, M., Collini, P., \& Quagli, A. (1996). Management Accounting in Italy: Evolution within Tradition. In Bhimani, A. (Ed.), Management Accounting. European Perspectives. Oxford: Oxford University Press.

Bertini, U. (1990). Scritti di politica aziendale. Torino: Giappichelli.

Besta, F. (1891, 1893). Corso di ragioneria professato alla classe di magistero nella R. Scuola Superiore di Commercio di Venezia. Parte Prima, Voll. I e II. Venezia: Fratelli Visentini.

Besta, F. (1909). La Ragioneria, Parte prima, Ragioneria generale, Voll. I e II, ristampa della seconda edizione riveduta e ampliata col concorso dei professori Vittorio Alfieri, Carlo Ghidiglia, Pietro Rigobon. Milano: Vallardi.

Buckmaster, D., \& Jones, S. (1997). From balance sheet to income statement: A study of a transition in accounting thought in the USA, 1926-1936. Accounting Auditing \& Accountability Journal, 10, 198-211.

Canziani, A. (1987). Sulle premesse metodologiche della rivoluzione Zappiana. Saggi di economia aziendale per Lino Azzini. Milano: Giuffrè.

Canziani, A. (1994). Gino Zappa, Accounting Revolutionary. In Edwards, J. R. (Ed.), Twentieth-Century Accounting Thinkers. London: Routledge.

Canziani, A. (2013). Accounting and 'Economia Aziendale' in Italy, 1911 Afterward. In Y. Biondi, \& S. Zambon (Eds.), Accounting and Business Economics. Insights from National Traditions. London: Routledge.

Carmona, S. (2004). Accounting history research and its diffusion in an international context. Accounting History, 9, 3. 


\section{MInstitute Macrothink $_{\text {Int }}$}

International Journal of Accounting and Financial Reporting

ISSN 2162-3082

Catturi, G. (1989). Teorie contabili e scenari economico aziendali. Padova: Cedam.

Ceccherelli, A. (1939). Il linguaggio dei bilanci. Formazione e interpretazione dei bilanci commerciali. Firenze: Le Monnier.

Ceriani, G. (1998). Il trasferimento dell'impresa in economia aziendale. ristampa con modifiche. Padova: Cedam.

Consorti, A. (2001). L'evoluzione della funzione informativa del bilancio d'esercizio: dal conto del patrimonio al sistema delle informazioni. Torino: Giappichelli.

Coronella, S. (2017). Financial valuations in the Italian patrimonialist tradition. In Alexander, D. et al. (Eds.), The History and Tradition of Accounting in Italy. London: Routledge.

Corticelli, R. (1981). Carattere specifico della valutazione di bilancio e accoglimento generale di principi contabili: considerazioni, Bilancio di esercizio e amministrazione delle imprese. Studi in onore di Pietro Onida. Milano: Giuffrè.

Costa, A., \& Tafuro, A. (2017). The financial statements in Aldo Amaduzzi's thought. In Alexander, D. et al. (Eds.), The History and Tradition of Accounting in Italy. London: Routledge.

D’Amico, L. (1999). Profili del processo evolutivo negli studi di economia aziendale. Schema di analisi per 'paradigmi' e 'programmi di ricerca scientifici'. Torino: Giappichelli.

D'Amico, L., \& Palumbo, R. (2017). The contribution of Maffeo Pantaleoni in the field of financial valuation. In Alexander, D. et al. (Eds.), The History and Tradition of Accounting in Italy. London: Routledge.

De Gobbis, F. (1925). Il bilancio delle società anonime. Milano: Società Editrice Dante Alighieri.

De Gregorio, A. (1908). I bilanci delle società anonime. Milano: Vallardi.

De Minico, L. (1935). Elasticità e relazioni dinamiche dei costi nelle imprese industriali. Napoli: Rondinella.

De Minico, L. (1946). Lezioni di ragioneria. I fondamenti economici della rilevazione del reddito (2nd ed.). Napoli: Pironti.

Di Pietra, R. (2017). Insights into the notion of goodwill from the Italian theoretical contribution. In Alexander, D. et al. (Eds.), The History and Tradition of Accounting in Italy. London: Routledge.

Di Pietra, R., McLeay, S., \& Riccaboni, A. (2001). La regolazione del Bilancio di esercizio: modelli teorici ed esperienza italiana. Rivista dei Dottori Commercialisti, 52, 901-936.

Di Stefano, G. (1991). Per una analisi delle cause esogene della crisi del sistema bestano. Rivista Italiana di Ragioneria e di Economia Aziendale. Roma, n. 9/10.

Faccipieri, S., \& Rullani, E. (1982). Regole di valutazione e indeterminatezza nella scienza 
economica d'azienda: un problema irrisolto nel pensiero di Gino Zappa. In La determinazione del reddito nelle imprese del nostro tempo alla luce del pensiero di Gino Zappa. Atti della giornata di studio nel centenario della nascita di Gino Zappa, Ca' Foscari, 4 aprile 1981. Padova: Cedam.

Ferrero, G. (1995). La valutazione del capitale di bilancio (updated edition by Bocchino, U.). Milano: Giuffrè.

Galassi, G. (1996). Zappa, Gino (1879-1960). In M. Chatfield, \& R. Vangermeersch (Eds.), The history of accounting: an international encyclopedia. New York: Garland Publishing.

Galassi, G., \& Mattessich, R. (1993). Italian Accounting Research in the First Half of the 20th Century. Review of Accounting and Finance, 3, 62-83.

Giannessi, E. (1960). Le aziende di produzione originaria, Vol. I, Le aziende agricole. Pisa: Cursi.

Giannessi, E. (1969). Considerazioni critiche intorno al concetto di azienda, Scritti in onore di Giordano Dell'Amore. Vol. I. Milano: Giuffrè.

Gonnella, E. (2012). Financial Statement Valuations in Italian Accounting Thought Between the 19th and the 20th Century: From 'Exchange Value' to 'Historical Cost'. Journal of Modern Accounting and Auditing, 8, 1255-1271.

Gonnella, E. (2017). The 'functional value' (valore funzionale) in the Tuscan School of 'Economia Aziendale': the contribution of Alberto Ceccherelli and Egidio Giannessi to financial valuation theory. In Alexander, D. et al. (Eds.), The History and Tradition of Accounting in Italy. London: Routledge.

Gonnella, E., \& Talarico, L. (2012). Italian Accounting of the Late 19th Century and the Early 20th Century on the Epistemological Problem of Connections with Related Sciences. Journal of Modern Accounting and Auditing, 8, 1095-1125.

Gonnella, E., \& Talarico, L. (2017), Teleological versus Non-Teleological Perspectives in Financial Statement: The Debate between Chambers and Onida. Accounting Historians Journal, 44, 157-179.

Lai, A. (2017). 'Consumable income' according to Edoardo Ardemani's thought. In Alexander, D. et al. (Eds.), The History and Tradition of Accounting in Italy. London: Routledge.

Lee, T. A. (1998). Income and Value Measurement: Theory and practice. London: Chapman \& Hall.

Lee, T. A. (2009). Financial Accounting Theory. In J. R. Edwards, \& S. P. Walker (Eds.), The Routledge Companion to Accounting History. London: Routledge.

Mattessich, R. (2008). Two hundred years of accounting research: an international survey of personalities, ideas and publications (from the beginning of the nineteenth century to the beginning of the twenty-first century). London-New York: Routledge. 


\section{MInstitute Macrothink $_{\text {Int }}$}

International Journal of Accounting and Financial Reporting ISSN 2162-3082

Onida, P. (1935). Il bilancio delle aziende commerciali. La determinazione del capitale di bilancio. Milano: Giuffrè.

Onida, P. (1940). Il bilancio d'esercizio nelle imprese. Significato economico del bilancio: problemi di valutazione (2nd ed.). Milano: Giuffrè.

Pantaleoni, M. (1904). Alcune osservazioni sulle attribuzioni di valori in assenza di formazione di prezzi di mercato. Giornale degli Economisti. Milano, n. 2.

Paolini, A., \& Soverchia, M. (2017). Fabio Besta: financial valuations at the beginning of the twentieth century in Italy. In Alexander, D. et al. (Eds.), The History and Tradition of Accounting in Italy. London: Routledge.

Parker, R. H. (2003). The scope of accounting history, Abacus, 29, 106-110.

Perrone, E. (1997). La ragioneria ed i paradigmi contabili. Padova: Cedam.

Poli, R. (1971). Il bilancio d'esercizio: evoluzioni e prospettive nell'economia dei paesi industrialmente progrediti. Milano: Giuffrè.

Previts, G. J., Parker, L. D., \& Coffman, E. N. (1990a). Accounting History: Definition and Relevance. Abacus, 26, 1-16.

Previts, G. J., Parker, L. D., \& Coffman, E. N. (1990b). An Accounting Historiography: Subject Matter and Methodology. Abacus, 26, 136-158.

Rossi, G. (1895). Valutazione economico-patrimoniale. In Cerboni, G. (Ed.), Enciclopedia di amministrazione industria e commercio. Milano: Vallardi.

Saggese, S., Caldarelli, A., \& Viganò, R. (2017). Financial valuations in Domenico Amodeo's thought. In Alexander, D. et al. (Eds.), The History and Tradition of Accounting in Italy. London: Routledge.

Salzano, A. (1938). L'assegnazione di valore al capitale in relazione al reddito futuro. Napoli: Il Piccolo Marittimo.

Schumpeter, J. A. (2006). History of Economic Analysis. London: Routledge.

Viganò, E. (1998). Accounting and Business Economics Traditions in Italy. European Accounting Review, 7, 381-403.

Viganò, E., \& Mattessich, R. (2007). Accounting research in Italy: second half of the 20th century. Review of Accounting and Finance, 6, 24-41.

Villa, F. (1870). Elementi di amministrazione e contabilità (5th ed.). Pavia: Bizzoni.

Whittington, G. (2010). Measurements in financial reporting. Abacus, 46, 104-110.

Zambon, S. (1996). Accounting and Business Economics Traditions: a Missing European Connection?. European Accounting Review, 5, 401-11.

Zambon, S., \& Zan, L. (2000). Accounting relativism: the unstable relationship between 


\section{Macrothink}

International Journal of Accounting and Financial Reporting

ISSN 2162-3082

income measurement and theories of the firm. Accounting, Organizations and Society, 25, 799-822.

Zan, L. (1994). Toward a History of Accounting Histories: Perspectives from the Italian Tradition. European Accounting Review, 3, 255-307.

Zappa, G. (1910). Le valutazioni di bilancio con particolare riguardo ai bilanci delle società per azioni. Milano: Società Editrice Libraria.

Zappa, G. (1920-29). La determinazione del reddito nelle imprese commerciali. I valori di conto in relazione alla formazione dei bilanci. Roma: Anonima Libraria Italiana.

Zappa, G. (1927). Tendenze nuove negli studi di ragioneria. Discorso inaugurale dell'anno accademico 1926-1927 nel R. Istituto Superiore di Scienze Economiche e Commerciali di Venezia. Milano: Istituto Editoriale Scientifico.

Zappa, G. (1935). Fabio Besta, il Maestro. Commemorazione letta a Ca' Foscari il 2 febbraio 1935. Milano: Giuffrè.

Zappa, G. (1939). Il reddito d'impresa. Scritture doppie, conti e bilanci delle aziende commerciali. (reprint of the 2nd ed.). Milano: Giuffrè.

\section{Notes}

Note 1. The Italian 'Commercial Code' of 1882, in force until 1942, did not prescribe any valuation criteria. The Code only provided for the following:

1) The general rule that 'the balance sheet must show, with evidence and truth, the profits actually achieved, and the losses suffered' (Article 176, par. 2);

2) The obligation to state, in the company's articles, 'the rules by which balance sheets must be prepared and earnings calculated and distributed' (Article 89, par. 1, 6).

It was only sixty years later, with the enactment of the Civil Code of 1942, that the legislative vacuum was filled with the first rules on valuations, contained in Article 2425. The situation left ample room for theorising on the subject by accounting and legal scholars. Among the latter, it is worth remembering De Gregorio (1908).

Note 2. In the quoted book, D'Amico and Palumbo examine the contribution of an economist, Maffeo Pantaleoni (1857-1924), to financial statement valuations; Paolini and Soverchia analyze the thought of Fabio Besta (1845-1922) on the subject at issue; Coronella observe the topic under discussion in the Italian patrimonialist tradition, formed by the contributions offered by scholars who lived between the nineteenth and twentieth centuries and were inspired by the teachings of Besta; Alexander, Fasiello and Giaccari focus on the theory proposed by Zappa (1879-1960); Gonnella studies the concept of 'functional valuation' formulated by Alberto Ceccherelli (1885-1958) and Egidio Giannessi (1908-1982), two members of the so called 'Tuscan School'; the thought of Aldo Amaduzzi (1904-1991) about financial statements is assessed by Costa and Tafuro; Azzali and Fornaciari study the 
contribution of Lino Azzini (1908-1986) to financial accounting and group accounting in Italy; Andrei and Corbella investigate the theories conceived by Carlo Masini (1914-1994) in the field of financial accounting; the ideas of Domenico Amodeo (1900-1901) on financial valuations are studied by Saggese, Caldarelli and Viganò; Adamo, Di Cagno and Imperiale analyze the notion of 'rational valuations' formulated by Paolo Emilio Cassandro (2010-2004); Di Pietra examines the Italian theoretical contribution about the notion of goodwill, and Lai studies the so called 'Consumable income' according to Edoardo Ardemani (1914-2006).

Note 3. The quoted passages of Italian writings have been translated into English by the author of this article.

Note 4. 'In Italian studies, the term azienda [within the framework of Economia Aziendale] is used with reference to different kinds of human organisations created and managed with the purpose of conducting an economic activity aimed to produce or consume/distribute wealth. Within such a framework, the notion of azienda includes both 'public organisations' and 'private organisations', namely public administrations like the State itself and its local governmental units, in the former group, and profit organizations or firms (also called businesses or enterprises) and not-for-profit organizations, such as foundations and associations (e.g. NGOs and other not-for-profit organizations) and households, in the latter group. More specifically, it should be pointed out that, in Italian studies, the enterprise is a special form of azienda whose prevalent function is the production of new wealth.' (Gonnella and Talarico, 2018, p. 492). See among others also: Viganò and Mattessich, 2007, pp. 25-26.

Note 5. Furthermore, Zappa observed: 'Within a coordinated whole... elements have a value which they lose when they are torn away from it. The patterns of aggregation of elements, their integration, their succession, converge... in shaping the characteristics of the whole. For reasons of scientific abstraction or of concrete approximate perception, the analysis can separate the unitary phenomenon in its elements, but it should not remain unaware of the "reality". And the relations which connect the part to the whole to which it pertains are not something which is fortuitous or extrinsic to "reality".' (Zappa, 1920-29, p. 331).

Note 6. Referring to Zappa's thought, Mattessich said: 'The "balance sheet capital" was determined through the interdependence of the values of its individual elements. In other words, the value of one item was seen as dependent on all the others and vice versa. This stems from the interdependence of the production factors represented by those values.' (2008, pp. 88-89).

Note 7. As regards the different procedures for the issuing of accounting regulations, an abstract distinction is usually made between the 'bureaucratic model', the 'delegate model' and the 'self-regulation model.' (Di Pietra, McLeay and Riccaboni, 2001, pp. 920-923).

Note 8. 'Italian law protected the interests of creditors by imposing a very conservative regime on inventory valuation, rather than requesting a 'true and fair view' of economic and financial position of firms.' (Bergamin Barbato et al., 1996, p. 149).

Note 9. It was the Commissione per la Statuizione dei Principi Contabili (CSPC, 


\section{Mll Macrothink}

International Journal of Accounting and Financial Reporting

ISSN 2162-3082

Commission for the definition of accounting principles), which started working in 1975. It is worthwhile remembering that, initially, the documents produced by the Commission and the related accounting principles had no prescriptive value. It was only in 1989 that the Commissione Nazionale per le Società e la Borsa (CONSOB, the National Commission for Companies and the Stock Exchange), with its own resolution, recommended that listed companies should implement Corretti Principi Contabili (Correct Accounting Principles), thus recognising for the first time the standards issued by CSPC (see: Di Pietra, McLeay and Riccaboni, 2001, p. 68 ff.).

Note 10. Schumpeter regards the theory of value as the 'causal explanation of the phenomenon of value' (Schumpeter, 2006, p. 309; see also Gonnella and Talarico, 2012, pp. 1115-1121).

Note 11. From among the first few authors that shared Alfieri's theses, let us mention De Gobbis, Onida and De Minico.

Note 12 . To briefly mention the valuation rationale developed by Alfieri, it might be helpful to recall that the scholar derived his theses from the fundamental distinction between 'true estimate' or 'actual estimate' or 'real estimate', on the one hand, and 'apparent estimate' or 'accounting estimate' or 'pseudo-estimate' on the other hand. The first type of estimate occurs when, as to a given thing, ' $\ldots$ one predicts the price that can be realised within a given time'; the second type occurs when '... one ideally replaces it with something else according to specific rules, which must be borne in mind when interpreting such replacement' (Alfieri 1925, 393). In particular, pseudo-estimates are classed by the scholar on the basis '...of the data they are built on or move from... in this way: a) estimate based on the market prices of things to be estimated; b) estimates based on the fruits that the things to be estimated are capable of bearing; c) estimate based on the costs of such things' (Alfieri, 1925, p. 397).

Note 13. For distinctions between 'going-concern' and 'liquidation' valuations in Italian accounting thought see Gonnella (2012).

Note 14. Regarding the early phase of Zappa's thinking about balance sheet valuations, see Gonnella (2012, pp. 1263-1267). Zappa, indeed, in the second instalment of his Reddito (Income), would disavow the theses he had developed precisely in his Valutazioni di Bilancio (Balance Sheet Valuations), where he labelled them as 'slavish and elementary disclosures' (Zappa, 1920-29, 328, no. 2). Regarding the fact that, as is known, it was precisely the second edition of this work that marked a dramatic change in the scholar's thought, see, among others, Giannessi (1969, pp. 472-473); Canziani (1987); Galassi and Mattessich (1993, pp. 64-68); and Viganò and Mattessich (2007, pp. 24-28).

Note 15 . Then, in the note on the same page, Zappa would also reject the old thesis ' $\ldots$ that the calculation of expenses, taken together, compose the cost of a product, which rests most of its certainty on real figures, the determination of which cannot be done either arbitrarily nor through ... any sort of entirely personal criteria ...'.

Note 16. 'This may appear, for instance, in times of rising prices or when higher revenues are assumedly certain to be realised. And, moreover, when costs are unknown as a sufficiently 
reliable quantity and the future revenues... may not even be the subject of conscious assumptions... Then financial statement value is not infrequently given by the current price or decreased by a higher or lower amount, mainly depending ... on the cautious forecast of earnings' (Zappa, 1920-29, p. 605).

Note 17. 'Even inventory valuations based on estimated revenue, deducted of collection costs, use of discounts, general risk allowance, etc.... cannot be rejected in itself when the realisation of the revenue may be consciously assumed as certain and forthcoming, regardless of such a revenue being higher or lower than cost' (Zappa, 1920-29, p. 608).

Note 18. The scholar reaches fairly similar conclusions even in connection with depreciations when, for example, he notices that '.. the estimate of yearly expenses... [may not] ... be done without knowing the specific circumstances provided by many and changeable firm and market conditions' (Zappa, 1920-29, p. 652). Zappa's 'limit values' thesis would then be taken up by Amaduzzi in his 1939 essay on Aspetti di problemi di valutazione nelle imprese industriali (Aspects of Valuation Problems in Industrial Enterprises). Then he would return to that subject in some later works such as Amaduzzi, 1947.

Note 19. 'An income allocation [to a different accounting period] that would depress a firm's future life, thus impairing it, would not be in keeping with its own purposes' (Amodeo, 1938, p. 29).

Note 20. 'What does 'not impairing the capital' mean ... but leaving its earnings capacity intact?’ (Amodeo, 1938, p. 30, no. 1).

Note 21. For a distinction between accounting as a science, as a technique and as an art, see also Giannessi (1960, pp. 465 and 743).

Note 22. To be precise, we refers to the transition from the so-called 'patrimonial or proprietorship system' to the so-called 'income system'. For more details on this topic, see, among others, Galassi and Mattessich (1993, 64-65), Zan (1994), Bergamin Barbato et al. (1996, pp. 141-144), Mattessich (2008, pp. 87-95). As is known, Zappa's inaugural lecture for the 1926-1927 academic year at the University of Venice, having the title Tendenze nuove negli studi di ragioneria (New trends in Accounting Research), published in 1927, had far more substantial effects in Italy than the birth of a new accounting system, i.e., the conception of a new science: the Economia Aziendale (see Canziani, 1994; Perrone, 1997; D’Amico, 1999).

Note 23. Amodeo, in particular, proved that '.. the precaution consisting in not damaging the firm's estimated future results, i.e., not depressing future earnings under the norm, may be fully accomplished when the value that was assigned to the capital as a result of financial statement valuations, from which net income is derived, does not exceed the economic value of the capital' (Amodeo, 1965, p. 761). See also, Amodeo (1943, p. 137). For an authorial review of the argument behind the comparison between economic capital and financial position as reflected in balance sheet, see Ceriani (1998, pp. 143-150).

Note 24. There is nothing to prevent finding that De Minico's statement is a refinement on 
Onida's. In this respect, Amodeo writes, for example, '... the 'non-impairment' of net income necessarily implies a reference to an 'unimpaired' net income: De Minico made this reference explicit by introducing the concept of 'normal' income' (Amodeo, 1938, p. 23).

Note 25 . The '... precautionary principle, in which the protection of firm profitability is expressed and which would have heavily affected quite a few business economics theories... is undoubtedly one of the greatest achievement of accounting' (Amodeo, 1965, p. 761).

Note 26. 'The conceptual achievement that was the development of a general valuation principle marks huge scientific progress. And such progress lies solely in the general position of such principle' (Amodeo, 1943, p. 139).

Note 27. It may be interesting to recall that the scholar advocates 'the different position of the financial and non-financial assets in connection with the valuation problem' (Ceccherelli, 1939, pp. 198-203).

Note 28. 'To the purposes of valuation, such components, even when they take a concrete form, lose their character of assets that, due to their inherent intrinsic qualities, may be estimated at any time. To be subjected to such kind of estimate, they should be separated from the whole by breaking it up' (Ceccherelli, 1939, pp. 189-190).

Note 29. Truth to tell, he had already written: 'The notion of operating quality and the degree of functionality of the assets thus seems to be naturally related to the events of a proper valuation' (Ceccherelli, 1939, p. 195).

Note 30. ' ... indeed, assets do have a value because a sum of money has been disbursed in order to take them, but, for the purposes of the financial statement results, they may or may not retain such value, depending on whether, at the time they are estimated, they are considered to be capable of producing an appropriate revenue within the company that uses them' (Ceccherelli, 1939, p. 195). And then, ‘... all valuation procedures, from historical cost depreciation to the future realisation price of assets for sales, by regarding the original cost as an operating value, in fact regard it as a monetary capital, capable of producing a given income and, by translating it into a financial statement value, they change its size according to variations in the assumed degree of functionality of the relative investments, which is tantamount to saying "according to the earnings capacity of the invested capital" (Ceccherelli, 1939, pp. 203-204).

Note 31. Ceccherelli writes: 'Financial statement valuation is oriented towards... the cost criterion. Which does not mean that capital components must be valued at cost; it only means that, in valuing them, which means valuing what remains of them, cost must be taken as the baseline' (Ceccherelli, 1939, p. 191). Then, he points out that '... the cost criterion... cannot become a valuation rule ...' (Ceccherelli, 1939, p. 197).

Note 32. '... a factor having an " $x$ " degree of usefulness might not be fully used within a firm if the other factors do not have a " $y$ ", " $z$ " or other degree of usefulness capable of combining with it in a useful way ...' (Giannessi, 1969, p. 513).

Note 33. Years later, Ferrero commented that '... relations of complementariness must be 


\section{Macrothink}

International Journal of Accounting and Financial Reporting

ISSN 2162-3082

taken into account..., as neglecting such relations and their 'weight' means determining a net worth in the balance sheet and an ensuing net income based on a gross conceptual mistake' (Ferrero, 1995, p. 105).

Note 34. The complementariness of assets and their implications on operating valuations had already been mentioned in many different forms by, among others, Besta (1909, II, p. 14); Pantaleoni (1904, pp. 219-221); Zappa (1910, pp. 112-113); Alfieri (1923, p. 268); and De Gobbis (1925, pp. 122-123). As to the fact that, according to Zappa, the complementariness of productive factors can only be understood with reference to the notion of economic capital, see Zappa (1939, pp. 96-102 and pp. 149-152). After all, years earlier, he had already stated that '... accounting valuations do not tend to determine the economic value of complementary goods ...' (Zappa, 1920-29, pp. 71-72).

Note 35. Speaking, for instance, of the valuation of machinery, Giannessi points out that 'the historical cost, the extraordinary maintenance and repair costs and the replacement costs are all elements of judgement but are not the judgement itself. To pass a judgement and conduct a functional valuation of the machine, the information found must be adapted to the specific firm and market conditions the calculation refers to' (Giannessi, 1960, p. 681).

Note 36. 'The term value takes on different meanings. Nevertheless, it always denotes an assessment, an opinion of human intelligence over assets' (Besta, 1909, p. 215).

Note 37. The same problem can also be observed in Anglo-Saxon studies. In this regard, Lee noted: '.. the financial accounting theory contributions of writers such as Hatfield, Paton, Chambers, and Sterling can be argued to have had marginal impact on the general state of practice and education ...' (Lee, 2009, p. 157).

\section{Copyright Disclaimer}

Copyright for this article is retained by the author(s), with first publication rights granted to the journal.

This is an open-access article distributed under the terms and conditions of the Creative Commons Attribution license (http://creativecommons.org/licenses/by/4.0/) 